\title{
Tax Revenue, Public Spending and Economic Growth in Cote d'Ivoire: Evidence on the Causality Issue
}

\author{
SORO Siongofolo Seydou \\ University Alassane Ouattara, Côte d'Ivoire (Bouaké), 21 BP 1783 Abidjan 21
}

\begin{abstract}
This paper examines the tax revenue and public spending nexus in Cote d'Ivoire in a multivariate framework using real Gross Domestic Product (GDP) as measure of economic growth over the period 1960 to 2019. The cointegration link among variables used ARDL, FMOLS, and DOLS estimators while the causality among variables was established employing Granger (1969) causality test and Toda and Yamamoto (1995) non-Granger causality test. Cointegration analysis affirms the existence of a long-run relationship between variables. The results of the causal analyses show a unidirectional causality running from tax revenue to public spending, supporting the "tax-and-spend" hypothesis. This implies that the Ivorian government does not first engages in spending and then later, to pay for this spending, it collects tax revenue. Because such a situation will exacerbate fiscal imbalance bearing in mind all the difficulties of collecting tax revenue in Cote d'Ivoire. Based on these findings, a credible strategy should focus more on spending cuts rather than look for ways to raise revenues.

Keywords: Tax revenue, Public spending, Economic growth, Cointegration, Causality, Côte d'Ivoire.
\end{abstract}

DOI: $10.7176 / \mathrm{JESD} / 12-16-07$

Publication date:August $31^{\text {st }} 2021$

\section{Introduction}

The relationship between tax revenue and public spending continues to be debated in the economic literature. In this regard, four theoretical points of view can be highlighted. The authors of the first point of view argue that public spending can have virtuous long-run effects on the economy, especially when used to finance public infrastructure, research and development, education and health (Barro, 1990; Lucas, 1988; Romer, 1990). This view is opposed by the view that budget deficits caused by expansionary fiscal policy can have a negative impact on the economy through its perverse effects on interest rates, inflation, savings and investment (Alesina and Ardana, 1998; Blanchard and Perotti, 1999; Giavazzi and al. 2000). As for the third point of view, the proponents of this point of view favor the idea of fiscal policy neutrality by attributing to private agents a capacity to anticipate state actions (Barro, 1974). Finally, the fourth point of view promotes the idea that restrictive fiscal policies can have positive effects on the economy (Giavazzi and Pagano, 1990).

However, the empirical results on the question are still mixed. Indeed, results in favor of the above four points of view have been found in economic literature. The fundamental question of this paper is therefore to know what is the meaning of the relationship between tax revenue and public spending in Côte d'Ivoire? In other words, does the growth in public spending lead to an increase in tax revenue or does the growth in tax revenue increase public spending? On the other hand, given that the objective of collected tax revenue as well as that of public spending incurred is to boost long-run economic growth, then the other relevant question is whether there is a cointegrating relationship between tax revenue, public spending and economic growth approximated by real Gross Domestic Product (GDP) in the long-run?

The main objective of this paper is to study the relationship between tax revenue, public spending and economic growth in Côte d'Ivoire. This specifically involves examining the causal relationship between tax revenue and public spending and assess the long-run effect between tax revenue, public spending and economic growth. This is a contribution to the empirical literature on the relationship between tax revenue and public spending and their impact on long-run in Côte d'Ivoire. To do this, the cointegration methods and causality tests will be used.

The rest of the paper is structured as follows. Section 2 is devoted to the literature review on the relationship between tax revenue and public spending. Section 3 describes the data of the study and presents the econometric methodology while Section 4 presents the empirical results. Finally, section 5 concludes the paper and discusses the implications of economic policies.

\section{Literature Review}

The relationship between tax revenue and public spending has given rise to an abundant literature, both theoretical and empirical. As mentioned in the introduction, the relationship can be divided into four hypotheses namely: (i) tax-and-spend hypothesis, (ii) spend-and-tax hypothesis, (iii) fiscal synchronization hypothesis and (iv) institutional separation hypothesis. Thus, the theoretical points of view as well as the empirical results are diverse and do not allow to reach a consensus on the direction of causality between the two variables. We discuss each hypothesis on a theoretical level as well as some empirical results supporting this hypothesis. 
The first stipulates a causality going in the direction of tax revenue towards public spending (tax-and-spend hypothesis). According to this assumption, public spending always adjusts, upward or downward, to any change in the level of budget revenue (Friedman, 1978; Anderson and al., 1986). Thus, an increase in tax revenue today would lead to an upward readjustment of public spending in the future. Under this assumption, tax hikes are not the right strategy since higher tax revenue would lead to higher public spending. Buchanan and Wagner (1978) share the same view that tax revenue cause government spending but consider a negative causal relationship. The tax-and-spend hypothesis has been supported by the following empirical studies: Brackley (1986), Manage and Marlow (1986), Marlow and Manage (1987) and Bohn (1991) for USA ; Owoye (1995) for Japan and Italy ; Darrat (1998) for Turkey ; Park (1998) for Corea ; Koren and Stiassny (1998) for United Kingdom, Germany and USA ; Chang and al. (2002) for Taiwan, South Korea, United Kingdom and Japan ; Chang and Ho (2002a) and Fuess and al. (2003) for Taiwan; Darrat (2002) for Lebanon and Tunisia; Payne and al. (2003) for Croatia ; Cheng (1999) for Colombia, Dominican Republic, Honduras, and Paraguay ; Ewing and Payne (1998) for Colombia, Ecuador and Guatemala ; Ahiakpor and Amirkhaldi (1989), Fasano and Wang (2002) for Bahrain, Oman, and the United Arab Emirates ; Guajardo and Pagan (2003) for Mexico ; Narayan (2005) for Indonesia, Singapore, Sri Lanka and Nepal ; Keho (2010) for Cote d'Ivoire ; Aworinde (2013) for Nigeria ; Obeng (2015) for Ghana ; Mohanty and Mishra (2017) for India ; Yinusa and Adedokun (2017) for Nigeria.

The second hypothesis postulates an inverse relationship going in the direction of public spending towards tax revenue (spend-and-tax hypothesis). According to this hypothesis, governments spend first and then increase tax revenue to finance their spending again (Peacock and Wiseman, 1979). These authors point out that the occurrence of economic, social and political upheavals generally leads to an increase in taxes initially used to finance the required increase in public spending. This is like the Ricardian equivalence theorem of Barro (1974). Following the Ricardian equivalence theorem, Barro (1974) shows that in the absence of fiscal illusion, an increase in public spending always leads to an increase in taxes. Studies providing support to the spend-and-tax hypothesis include Anderson and al. (1986), von Furstenberg and al. (1986), Ram (1988a), Jones and Joulfaian (1991), Joulfaian and Mookerjee (1991) and Islam (2001) for USA ; Hondroyiannis and Papapetrou (1996) and Vamvoukas (1997) for Greece; Dhanasekaran (2001) for India ; Mithani and Khoon (1999) for Malaisia ; Koren and Stiassny (1998) for France ; Carneiro and al. (2004) for Guinea-Bissau ; Dogan (2013) for Turkey ; Paleologou (2013) for Greece ; Lukovic and Grbic (2014) for Serbia ; Nwosu and Okafor (2014) for Nigeria ; Tiwari and Mutascu (2015) for Romania ; Abdulrasheed (2017) for Nigeria.

The third hypothesis supports the idea of bidirectional causality between tax revenue and public spending (Musgrave, 1966; Meltzer and Richard, 1981). There would thus be an assumption of synchronization in the decisions of tax revenue and public spending through an analysis of the costs and benefits of alternative programs. Some empirical studies have succeeded in establishing a bidirectional causality between tax revenue and public spending, thus validating the hypothesis of synchronization of tax revenue and public spending decisions. Evidence supporting the fiscal synchronization hypothesis was reported by Miller and Russek (1990), Owoye (1995) for USA ; Bath and al. (1993) for India ; Hasan and Lincoln (1997) for United Kingdom ; Cheng (1999) for Chile, Panama, Brazil and Peru ; Li (2001) and Chang and Ho (2002b) for China ; De Castro and al. (2004) for Spain; Baffes and Shah (1994) for Argentina and Mexico ; Ewing and Payne (1998) for Chile and Paraguay ; Fasano and Wang (2002) for Kuwait, Qatar and Saudi Arabia ; Baghestani and AbuAl-Foul (2004) for Jordan; Phiri (2016) for South Africa ; Al-Zeaud (2014) for Jordan ; Takumah (2014) for Ghana ; Ibrahim (2017) for Nigeria ; Aworinde and Ogundipe (2015) for Nigeria ; Athanasenas and al. (2014) for Greece; Paleologou (2013) for Sweden and Germany.

Finally, the fourth hypothesis considers the possibility of independence in the determination of tax revenue and public spending. This independence would be due to an institutional separation of the functions of allocation and taxation of resources (Hoover and Sheffrin, 1992). According to the authors of this hypothesis, decisions on public spending and tax revenue are made independently of each other due to the divergent views and interests of different parties or groups. Empirical results in favor of the independence hypothesis have been found by Hoover and Sheffrin (1992), Baghestani and McNown (1994) for USA; Ram (1988b) for India, Panama, Paraguay and Sri Lanka; Narayan (2005) for India, Malaysia, Pakistan, Thailand and the Philippines.

The review of empirical literature shows that the question of the direction of causality between tax revenue and public spending is far from finding a definitive answer. The results depend on the country, the data but also the methodologies used to conduct the causality tests. The lack of unanimity in the empirical results may be due to differences in traditions of economic policies, methodological issues as well as the data.

\section{Data and Econometric methodology}

This paper seeks to examine which of the four assumptions set out above characterizes the temporal relationship between tax revenue and public spending in Côte d'Ivoire and how these variables affect each other in the longrun. To do this, we first apply the cointegration approach of Pesaran and al. (2001) to examine the long-run cointegration relationship between the variables. Also, to capture long-run effects between the variables we use 
the FMOLS and DOLS estimators to check robustness. Secondly, we analyze causality in the sense of Granger (1969) and the approach of Toda and Yamamoto (1995).

\subsection{Data}

This paper uses annual data on tax revenue $(\mathrm{T})$, public spending $(\mathrm{S})$ and Gross Domestic Product $(\mathrm{Y})$ as measure of economic growth over the period 1960 to 2019. Data are viewed in real terms using the Gross Domestic Product deflator. In addition, the variables are expressed in logarithmic form. From a statistical point of view, this transformation makes it possible to reduce the variance of the series and thus increase the probability to obtain stationary series in first differences. From an economic point of view, the logarithmic transformation allows us to interpret, on the one hand, the series in first differences in terms of growth rate and, on the other hand, the relationships between the variables in terms of elasticities. Nominal data on tax revenue, public spending and nominal Gross Domestic Product are taken from the BCEAO 2020 database. The Gross Domestic Product deflator is taken from the World Bank 2020 database.

\subsection{Econometric methodology}

The empirical methodology of this paper unfolds in three steps. The first step examines the stationarity of the variables using unit root tests. The second step tests the presence of long-run relationships while the third step is to carry out causal relationships among the variables.

The first step determines the order of integration of each variable. For this purpose, we use the standard tests of Dickey-Fuller Augmented (ADF, 1979), Phillips and Perron (PP, 1988) and Elliott and al., (DF-GLS, 1996). However, some authors have shown that these standard tests are biased in favor of not rejecting the hypothesis of non-stationarity when the series studied presents a structural change (Perron, 1989; Zivot and Andrews, 1992). The period of analysis of the paper comprises several phases of evolution of the Ivorian economy, namely the period of crisis and structural adjustment (1981-1993), the post-devaluation period (19941999), the period socio-political instability (2000-2011) and finally the period of socio-political stability (20122019). These phases are likely to distort unit root tests if they are completely ignored. To take this potential bias into account, we use the test of Zivot and Andrews (1992). This test has the advantage of not requiring the a priori specification of the possible timing of structural breaks. The break dates are endogenously determined within the model. We use two versions of the Zivot and Andrews (1992) sequential trend break model. Model A allows for a change in intercept while model $\mathrm{C}$ allows for a change in both the intercept and slope. Model $\mathrm{A}$ involves running the following regression:

$$
\Delta H_{t}=\mu+\beta t+\theta D U_{t}+\alpha H_{t-1}+\sum_{t=1}^{k} C_{j} \Delta H_{t-j}+e_{t}
$$

Model $\mathrm{C}$ takes the following form:

$$
\Delta H_{t}=\mu+\beta t+\theta D U_{t}+\gamma D T_{t}+\alpha H_{t-1}+\sum_{t=1}^{k} C_{j} \Delta H_{t-j}+e_{t}
$$

where $\Delta_{\text {is }}$ the first difference operator, $D U_{t}$ and $D T_{t}$ are dummy variables for a mean shift and a trend shift defined as: $D U_{t}=1$ if $t>T_{b}$ and 0 otherwise; $D T_{t}=t-T_{b}$ if $t>T_{b}$ and 0 otherwise. The $k$ extra regressors are included to address the problem of autocorrelation in the error term $e_{t}$. A test of the unit root hypothesis has the null $\alpha=0$. The alternative hypothesis is that the series $H_{t}$ is trend stationary with a structural break in the trend function. The searching for breakpoint $\left(T_{b}\right)$ is performed by running a set of regressions and by choosing the breakpoint for which the t-statistic $T_{\alpha}$ for $\alpha$ is minimized.

The second step examines the possible presence of a cointegrating relationship between tax revenue, public spending and GDP. Several procedures have been suggested to test for the presence of cointegration between two or more variables. We apply the approach proposed by Pesaran and al. (2001) which is based on autoregressive distributed lag model (ARDL). The main advantage of this approach is that it can be applied regardless of the orders of integration of the regressors. Thus, it reduces the uncertainties inherent in preliminary unit root tests. Another advantage of the test of Pesaran and al. (2001) is that it is relatively more efficient for small samples in which the order of integration of the variables is not well known or might not necessarily be the same. This method has been shown to provide unbiased estimates of long-run coefficients and valid t-statistics even when some explanatory variables are endogenous (Inder, 1993). The ARDL bounds testing approach to cointegration is based on the following error-correction model:

$$
\Delta S_{t}=\alpha_{1}+\emptyset_{1} D_{t}+\beta_{1} S_{t-1}+\beta_{2} T_{t-1}+\beta_{3} Y_{t-1}+\sum_{i=1}^{p} \theta_{i} \Delta S_{t-i}+\sum_{i=0}^{p} \gamma_{i} \Delta T_{t-i}+\sum_{i=0}^{p} \delta_{i} Y_{t-i}+\varepsilon_{t}
$$

Where $\Delta$ is the difference operator, $D_{t}=\left(D_{1 t}, D_{2 t}\right)$ denotes a vector of dummy variables capturing the periods of crisis from 1978, post devaluation and adoption of the convergence criteria in 1994: $D_{1 t}=1_{\text {for }}$ $t<1977$ and zero otherwise; $D_{2 t}=1$ for $t<1993$ and zero otherwise. $S_{t}, T_{t}$ and $Y_{t}$ denote the real 
public spending, the real tax revenue and the real GDP respectively. Equation (3) is estimated using each variable as the dependent variable. The presence of long-run relationship is tested by restricting coefficients of lagged level variables equal to zero. In other words, the null hypothesis of no long-run relationship is: $H_{0}: \beta_{1}=\beta_{2}=\beta_{3}=0$. This hypothesis is tested by an F-test. The asymptotic critical values are provided by Pesaran et al. (2001). However, it should be noted that the critical values provided by Pesaran et al. (2001) are calculated based on large samples of the order of 500 and 1000 observations, and 2000 and 40000 replications, respectively. Thus, Narayan (2005) produced a new set of critical values for small samples ranging from 30 to 80 observations. The sample size is not large (60 observations), so we use the critical values provided by Narayan (2005). In addition, the ARDL procedure is sensitive to the selection of the lag structure (p). In this study, the maximum lag length on each variable was set to one and the optimal lag structure was selected using the Akaike Bayesian information criteria (AIC). Also, the dynamic ordinary least squares (DOLS) of Stock and Watson (1993) and the fully modified ordinary least squares (FMOLS) of Phillips and Hansen (1990) model are employed for a robustness check. DOLS model avoids endogeneity and serial correlation problems by incorporating the first difference of nonstationary regressors and also the leads and lags of the first difference regressors (Stock and Watson 1993) while the FMOLS model as OLS estimators might appear to be inconsistent and biased as a result of potential multicollinearity, endogeneity, and serial correlation problems.

The third step concerns the causality tests between the variables since the main purpose of our study is to establish the causal linkages between tax revenue and public spending with GDP as a control variable. To do this, we apply the Granger (1969) causality approach and procedure of Toda and Yamamoto (1995). Accordingly, the Granger causality test within the VECM will be based on the following regression:

$$
\begin{aligned}
& \Delta S_{t}=\alpha_{1}+\sum_{i=1}^{p} \beta_{1 i} \Delta S_{t-i}+\sum_{i=1}^{p} \gamma_{1 i} \Delta T_{t-i}+\sum_{i=1}^{p} \emptyset_{1 i} Y_{t-i}+\lambda_{1} e_{t-1}+\pi_{1} D_{t}+\mu_{1 t} \\
& \Delta T_{t}=\alpha_{2}+\sum_{i=1}^{p} \beta_{2 i} \Delta S_{t-i}+\sum_{i=1}^{p} \gamma_{2 i} \Delta T_{t-i}+\sum_{i=1}^{p} \emptyset_{2 i} Y_{t-i}+\lambda_{2} e_{t-1}+\pi_{2} D_{t}+\mu_{2 t}
\end{aligned}
$$

where $e_{t-1}$ stands for the lagged error correction term derived from the long-run cointegrating relationship. An error correction model enables one to distinguish between long-run and short-run Granger causality and identify two different sources of causality. The short-run dynamics are captured by the individual coefficients of the lagged differenced terms. The statistical significance of the coefficients of each explanatory variable are used to test for short-run Granger-causality while the significance of the coefficients of $e_{t-1}$ gives information about long-run causality. It is also desirable to test whether the two sources of causation are jointly significant. To complement the causality analysis, we also implement the Granger-causality test proposed by Toda and Yamamoto (1995) as an alternative approach to test for long-run causality. This approach has the advantage of not requiring pre-testing for cointegration properties of the system and can be implemented irrespective of whether the underlying variables are stationary, or integrated of different orders, cointegrated or noncointegrated. The Toda and Yamamoto procedure essentially involves the determination of the maximum likely order of integration $\left(d_{\max }\right)$ of the series in the model and the estimation of the following VAR:

$$
Z_{t}=\Phi_{0}+\sum_{i=1}^{p *} \Phi_{i} Z_{t-i}+\mu_{t}
$$

where $Z_{t}=\left(S_{t}, T_{t}, Y_{t}\right)^{\prime} p *=k+d_{\max }$ and $\Phi_{i}$ are $(3 \times 3)$ coefficient matrices. Once this augmented level VAR is estimated, a standard Wald test is applied to the first lagged $k$ explanatory variables to make causal inference. The last lagged $d_{\max }$ coefficients are ignored because the inclusion of extra lags is to ensure that the computed Wald-statistic has an asymptotic chi-square distribution with the degree of freedom equal to the number of constraints.

\section{Empirical Results and Discussion}

In the empirical analysis, we proceed as follows. First, we perform a descriptive analysis of the variables. Next, we apply unit root tests to determine the order of integration of the variables. Third, we apply the cointegration test and estimate the long-run coefficients. Finally, we test causality using the test of Granger (1969) and the Toda and Yamamoto (1995) procedure.

\subsection{Descriptive statistics}

Figure 1 presents the trend of tax revenue and public spending during the sample period. We can see that the two variables have been oscillating during the period 1960 to 2019. Upon closer examination, Figure 1 clearly shows that Côte d'Ivoire had a roughly balanced budget during the period 1960 to 1977. The public spending increased significantly in 1978 exceeding the tax revenue and the gap between tax revenue and public spending has widened and has tended to persist since 1978. Given the trends depicted in Figure 1, we cannot ascertain whether the government has been using a policy of tax-and-spend or spend-and-tax rule or whether spend and tax decision was jointly determined. 


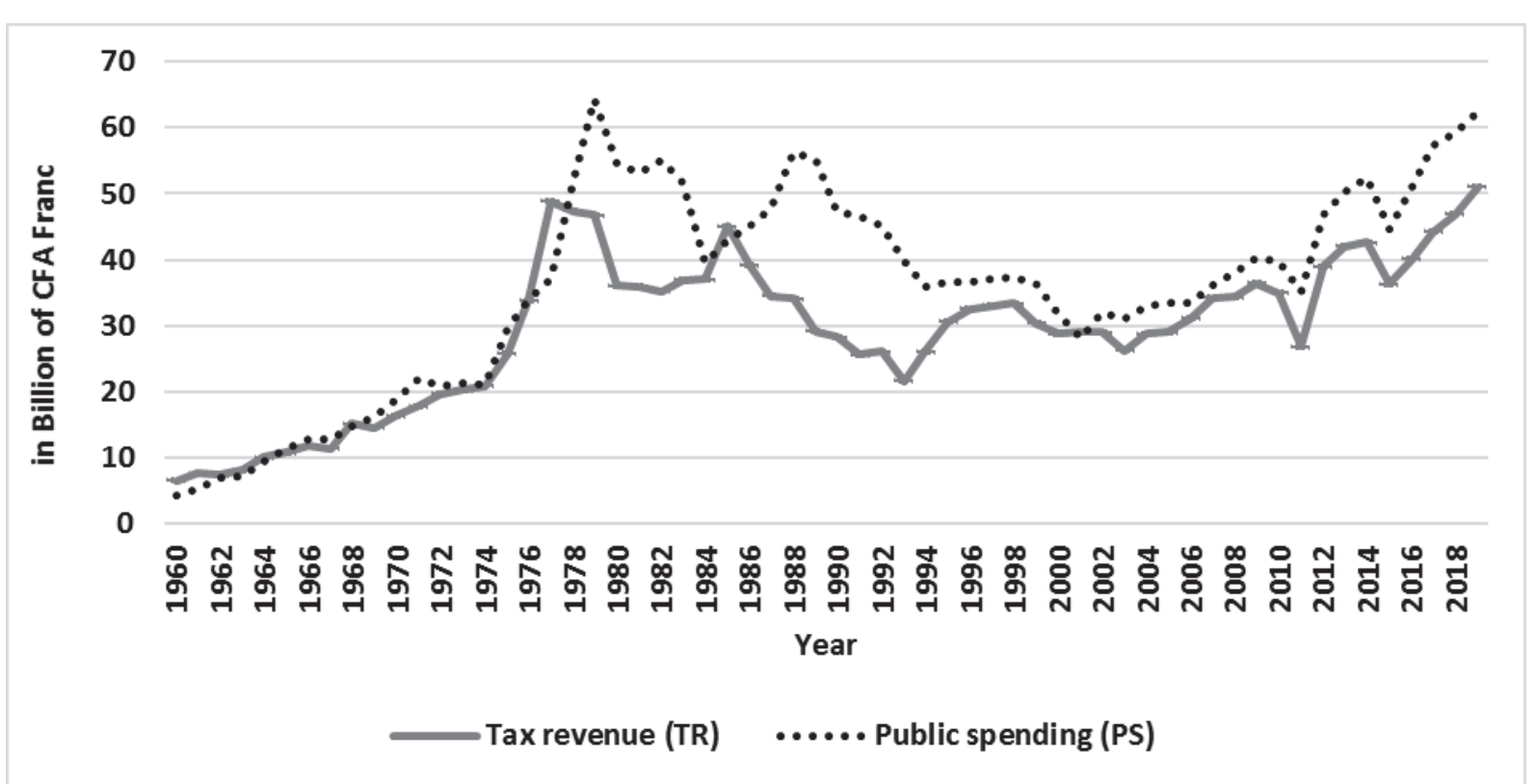

Figure 1: Tax revenue (TR) and Public spending (PS) over time, 1960 - 2019.

We then look at the descriptive statistics for the three variables of the study. The results of the descriptive statistics of the study are reported in Table 1. In panel A, we can observe that the log of real GDP has an average level of 25.66 and a standard deviation of 0.66 . Also, the log of real tax revenue has an average level of 23.99 and a standard deviation of 0.51 . Likewise, the log of real public spending has an average level of 24.15 and a standard deviation of 0.63 . It can also be observed that the standard deviations are very small since the variables have been transformed into a logarithm. This makes the stationarity of the variables more probable.

In panel $\mathrm{B}$, the correlation matrix indicates a positive relationship between all variables. However, correlation does not imply causality. A positive correlation between tax revenue and public spending may be compatible with the public spending hypothesis driven by tax revenue, the tax revenue hypothesis driven by public spending or a bidirectional causality between tax revenue and public spending or the independence hypothesis of the two variables. Is there a causality between tax revenue and public spending in Cote d'Ivoire? The temporal causal relationship between public spending and tax revenue could be any of the four hypotheses. Table 1 : Descriptive statistics and correlation matrix.

$\begin{array}{cccc}\text { Gross Domestic } & \text { Tax Revenue } & \\ \text { Product }(\log ) & (\log ) & \text { Public Spending }(\log ) \\ \text { Panel A : Summary Statistics } & & 23.998 & 24.158 \\ \text { Mean } & 25.667 & 24.140 & 24.333 \\ \text { Median } & 25.792 & 0.513 & 0.634 \\ \text { Std. Dev. } & 0.662 & 24.656 & 24.885 \\ \text { Maximum } & 26.593 & 22.609 & 22.180 \\ \text { Minimum } & 24.305 & 60 & 60 \\ \text { Observations } & 60 & & \\ \text { Panel B : Correlation Matrix } & & & \\ \text { Gross Domestic Product (log) } & 1.000 & 1.000 & 1.000 \\ \text { Tax Revenue (log) } & 0.744^{*} & 0.954^{*} & \\ \text { Public Spending (log) } & 0.749^{*} & \end{array}$

Notes: $*$ and $* *$ indicate significance at the $1 \%$ and $5 \%$ levels.

\subsection{Unit root tests}

Before we proceed to cointegration tests, we must test the order of integration of the variables. To test the stationarity properties of the series, we begin through applying the unit root tests of Augmented Dickey and Fuller (1979), Phillips and Perron (1988) and Elliott and al. (1996). These tests are denoted as ADF, PP and DFGLS respectively.

The DF-GLS test is a simple modification of the Augmented Dickey-Fuller (ADF) t-test as it applies generalized least squares (GLS) detrending prior to running the ADF test regression. Compared with the ADF test, the test has the best overall performance in terms of sample size and power (Elliott and al., 1996). The three tests have been performed under the model with constant and trend. The results reported in Table 2 reveal that the series are non-stationary in their levels but become stationary after taking the first difference. 
Table 2 : Résultats des tests de racine unitaire ADF, PP et DF-GLS

\begin{tabular}{|c|c|c|c|c|c|c|}
\hline \multirow{2}{*}{ Variables } & \multicolumn{3}{|c|}{ Level } & \multicolumn{3}{|c|}{ First difference } \\
\hline & ADF & PP & DF-GLS & ADF & PP & DF-GLS \\
\hline $\begin{array}{l}\text { Gross Domestic Product } \\
(\log )\end{array}$ & -2.751 & -2.619 & $-2,227$ & $-8.123 *$ & $-11.696^{*}$ & $-8,184 *$ \\
\hline $\begin{array}{l}\text { Tax Revenue } \\
\quad(\log )\end{array}$ & -2.310 & -2.332 & $-1,394$ & $-7.092 *$ & $-7.095 *$ & $-7,037 *$ \\
\hline Public Spending (log) & -3.123 & -3.051 & $-1,170$ & $-6.222 *$ & $-6.214^{*}$ & $-6,149 *$ \\
\hline Critical values : $1 \%$ & -4.121 & -4.121 & -3.736 & -4.124 & -4.124 & -3.739 \\
\hline $5 \%$ & -3.488 & -3.488 & -3.161 & -3.489 & -3.489 & -3.164 \\
\hline $10 \%$ & -3.172 & -3.172 & -2.863 & -3.173 & -3.173 & -2.866 \\
\hline
\end{tabular}

Note: $*$ and $* *$ indicate significance at the $1 \%$ and $5 \%$ levels. These tests are relating to the model with constant and trend.

Given the inability of standard unit root tests to capture structural breaks, we apply the Zivot and Andrews (1992) sequential one-break test. The test statistics together with the critical values are reported in Table 3. Clearly, the tests results do not show evidence against the existence of a unit root even when breaks are allowed. Finally, we can consider the series as realizations of integrated processes of order one (I (1)).

Table 3 : Zivot and Andrews test for unit roots with one structural break

\begin{tabular}{ccccc}
\hline \hline \multirow{2}{*}{ Modèles } & & $\begin{array}{c}\text { Gross Domestic } \\
\text { Product }(\log )\end{array}$ & $\begin{array}{c}\text { Tax Revenue } \\
(\log )\end{array}$ & Public Spending (log) \\
\hline \hline \multirow{3}{*}{$\mathbf{A}$} & $\mathbf{Z A}$ & $-4,386$ & $-3,141$ & $-4,296$ \\
& $\mathbf{V C e} \boldsymbol{t}_{\boldsymbol{\alpha}}$ & $-4,930$ & $-4,930$ & $-4,930$ \\
& $\boldsymbol{T}_{\boldsymbol{b}}$ & 1979 & 1987 & 1990 \\
\hline \hline \multirow{3}{*}{$\mathbf{C A}$} & $\mathbf{Z A}$ & $-5,031$ & $-3,108$ & $-2,965$ \\
& $\mathbf{V C e} \boldsymbol{t}_{\boldsymbol{\alpha}}$ & $-5,080$ & $-5,080$ & $-5,080$ \\
& $\boldsymbol{T}_{\boldsymbol{b}}$ & 1990 & 1986 & 1975 \\
\hline \hline
\end{tabular}

Note: ZA are the Zivot-Andrews 1992 t-statistics. VCe is the exact critical value at the 5\% level. $T_{b}$ indicates the date of break point. A is the model with intercept while $C$ is the model with intercept and trend.

\subsection{Results of cointegration tests}

We now examine the presence of a cointegrating relationship between the variables. To do this, we applied the bounds test of Pesaran and al. (2001). The results of the bounds test F-statistics as well as the critical values of this test are reported in Table 4 when each variable is considered as a dependent variable. The results indicate that the null hypothesis of no cointegration can be rejected at the $1 \%$ significance level when tax revenue and public spending is used as the dependent variable. Thus, we can conclude that there exists a long-run relationship between tax revenue, public spending and GDP when the regressions are normalized on public spending or tax revenue. This implies that tax revenue, public spending, and GDP have been moving together from 1960 to 2019 . Table 4 : Bounds test results

\begin{tabular}{|c|c|c|c|c|c|c|}
\hline Dependent variable & \multicolumn{2}{|c|}{$\bar{F}_{I I}$} & \multicolumn{2}{|c|}{$F_{I I I}$} & \multicolumn{2}{|c|}{ "Cointegration? } \\
\hline $\begin{array}{c}\text { Gross Domestic Product } \\
(\log )\end{array}$ & \multicolumn{2}{|c|}{3.392} & \multicolumn{2}{|c|}{2.724} & \multicolumn{2}{|c|}{ No } \\
\hline Tax Revenue (log) & \multicolumn{2}{|c|}{$5.326^{*}$} & \multicolumn{2}{|c|}{$6.368 *$} & \multicolumn{2}{|c|}{ Yes } \\
\hline Public Spending (log) & \multicolumn{2}{|c|}{$7.682 *$} & \multicolumn{2}{|c|}{$8.779 *$} & \multicolumn{2}{|c|}{ Yes } \\
\hline \multicolumn{7}{|c|}{ Exact critical value bounds for F-statistics } \\
\hline \multirow[t]{2}{*}{ Statistic } & \multicolumn{2}{|c|}{$1 \%$} & \multicolumn{2}{|c|}{$5 \%$} & \multicolumn{2}{|c|}{$10 \%$} \\
\hline & $\mathbf{I}(\mathbf{0})$ & I(1) & $\mathbf{I}(\mathbf{0})$ & $\mathbf{I}(\mathbf{1})$ & $\mathbf{I}(\mathbf{0})$ & I(1) \\
\hline$F_{I I}$ & 4.068 & 5.250 & 2.962 & 3.490 & 2.496 & 3.346 \\
\hline$F_{I I I}$ & 4.748 & 6.188 & 3.415 & 4.615 & 2.838 & 3.923 \\
\hline
\end{tabular}

Notes: $\overline{F_{11}}$ and $\overline{F_{111}}$ are the $F$-statistics for cases II and III, respectively (Pesaran et al., 2001). The exact critical values are from Narayan (2005). * Denotes the rejection of the null hypothesis at the 1\% significance level.

After finding the existence of cointegration relation between the variables, we estimate the long-run and short-run effects of tax revenue, public spending and GDP. We estimate the long-run relationship using three different techniques, namely the dynamic ordinary least squares (DOLS) estimator suggested by Stock and Watson (1993), the fully modified ordinary least squares (FMOLS) introduced initially by Phillips and Hansen (1990) then extended by Phillips (1995) and the autoregressive distributed lag (ARDL) model from Pesaran and 
al. (2001). This last model has the advantage that it allows simultaneous estimation of the long-run and short-run relationship. Our use of more than one technique is crucial for the sign on the coefficient on tax revenue because it will enable us to interpret the Granger causality results correctly.

The results on the long-run are disclosed in Table 5. We can observe in the long-run relationship that tax revenues have a significant positive effect at the $5 \%$ level on public spending. Thus, tax revenue and public spending are positively related in the long-run. This suggests that an increase in tax revenue has a positive effect on public spending. In view of the results of Table 5, a 1\% increase in tax revenue leads to an increase of more than $0.80 \%$ in public spending. However, the results show that real GDP does not affect public spending. This indicates that there is no relationship between public spending with economic growth.

Table 5 : Long-run estimates

\begin{tabular}{|c|c|c|c|c|c|c|}
\hline \multirow{3}{*}{ Regressor } & \multicolumn{6}{|c|}{ Dependent variable: Public Spending (log) } \\
\hline & \multicolumn{2}{|c|}{ ARDL } & \multicolumn{2}{|c|}{ FMOLS } & \multicolumn{2}{|c|}{ DOLS } \\
\hline & Coeff. & t-stat. & Coeff. & t-stat. & Coeff. & t-stat. \\
\hline $\begin{array}{l}\text { Tax Revenue } \\
\text { (log) }\end{array}$ & $0.884^{*}$ & 7.182 & $0.815^{*}$ & 8.723 & $0.865^{*}$ & 6.165 \\
\hline $\begin{array}{c}\text { Gross Domestic Product } \\
(\log )\end{array}$ & 0.020 & 0.158 & $0.175 * *$ & 2.034 & 0.129 & 1.004 \\
\hline
\end{tabular}

Notes: $*$ and $* *$ denotes statistical significance at the $1 \%, 5 \%$ and $10 \%$ level.

The short-run dynamics results are reported in Table 6 . The coefficient on the lagged error correction term is significant with the correct sign, supporting the evidence of a stable long-run relationship among the variables. This coefficient suggests that a deviation from the long-run equilibrium level of public spending in one year is corrected by $37 \%$ over the following year. The elasticity of public spending with respect to tax revenue in the short-run is positive and statistically significant. In the short-run, tax revenue contributes to public spending. However, we do not find statistical significance for the GDP. Although cointegration suggests the presence of Granger causality of some form between the variables, it does not provide information on the direction of causal relationships. We then examine the direction of causality.

Table 6 : Short-run estimation results

\begin{tabular}{lccc}
\multicolumn{2}{c}{ Regressor } & \multicolumn{2}{c}{ Dependent variable: Public Spending $(\log )$} \\
\cline { 2 - 3 } & Coeff. & t-stat. & Prob. \\
\hline \hline$\Delta($ Tax Revenue $(\log ))$ & $0.495^{*}$ & 5.468 & 0.000 \\
$\Delta($ Gross Domestic Product $(\log ))$ & $0.228^{* *}$ & 1.969 & 0.054 \\
ECM $(-1)$ & $-0.366^{*}$ & -6.764 & 0.000 \\
\hline \hline
\end{tabular}

Notes: * and ** denotes statistical significance at the $1 \%$ and $5 \%$ level.

\subsection{Results of causality tests}

The results of the causality test of Granger (1969) reported in tables 7 show that there is a positive long-run unidirectional causality running from tax revenue to public spending. Evidence suggests that tax revenue cause public spending, which supports the " tax-and-spend hypothesis" that is justified by some previous studies such as Brackley (1986), Manage and Marlow (1986), Marlow and Manage (1987) and Bohn (1991) for USA; Guajardo and Pagan (2003) for Mexico; Narayan (2005) for Indonesia, Singapore, Sri Lanka and Nepal; Keho (2010) for Cote d'Ivoire.

Table 7 : Pairwise Granger test results

\begin{tabular}{ccccc}
\hline Null Hypothesis & Obs. & F-Statistic & Prob. & Causality \\
\hline LNPS does not Granger Cause LNTR & 59 & 0.073 & 0.788 & LNPS $\neq$ LNTR \\
LNTR does not Granger Cause LNPS & 59 & 11.450 & 0.001 & LNTR $\rightarrow$ LNPS \\
\hline \hline
\end{tabular}

Notes: LNTR denote the log of real tax revenue and LNPS denote the log of real public spending.

Such evidence is further supported by the results of Toda and Yamamoto (1995) procedure reported in Table 8. These results confirm that there is a positive unidirectional causality running from tax revenue to public spending. Considering these findings, we can conclude that there is a unidirectional causal link running from tax revenue, which lends support to the "tax-and-spend hypothesis" for the Côte d'Ivoire. This implies that growth in public spending in Cote d'Ivoire has been influenced greatly by the availability of funds to finance this spending. Under this scheme, raising tax revenue to deal with the problem of persistent budget deficits would be completely effective since higher tax revenue would lead to higher public spending. The government should try to raise tax revenue to restore fiscal discipline and control the size of its public deficit in the long-run. 
Table 8 : Toda and Yamamoto Granger non-causality tests.

\begin{tabular}{|c|c|c|c|c|c|c|}
\hline \multirow[b]{2}{*}{$\mathbf{p}$} & \multirow[b]{2}{*}{$d_{\max }$} & \multicolumn{2}{|c|}{ LNTR causes LNPS } & \multicolumn{2}{|c|}{ LNPS causes LNTR } & \multirow{2}{*}{ Causality } \\
\hline & & Wald Stat. & P-value & Wald Stat. & P-value & \\
\hline 1 & 1 & $12.910 *$ & 0.000 & 0.062 & 0.802 & $\mathrm{LNTR} \rightarrow \mathrm{LNPS}$ \\
\hline 2 & 1 & $11.095 *$ & 0.004 & 0.669 & 0.715 & $\mathrm{LNTR} \rightarrow \mathrm{LNPS}$ \\
\hline
\end{tabular}

Notes: $p$ is the lag length of the level VAR and $d_{\max }$ is the maximal order of integration of the series in the system.

* Denotes statistical significance at the 1\% level.

\section{Conclusion}

The causal relationship between tax revenue and public spending is widely discussed in the economic literature and the controversy still exists on whether higher tax revenue leads to higher public spending or vice versa. Rather than using a two-variables model, we conducted the analysis in a multivariate statistical framework using economic growth approximated by real Gross Domestic Product as the control variable. This study used annual data covering the period 1960 to 2019 to examine the temporal causal relationship between tax revenue and public spending. Using the bounds test approach of Pesaran et al. (2001), we found clear evidence of a long-run relationship among real tax revenue, real public spending and real GDP. In this cointegrating relationship, tax revenue has a positive effect on public spending, but real GDP has no effect on public spending. The results of causality tests from the Granger (1969) and the Toda and Yamamoto (1995) suggest a long-run unidirectional causality running from tax revenue to public spending. Considering these findings, we can conclude that ivorian authorities follows the "tax-and-spend" scheme.

Our empirical findings have important economic policy implications. First, it should be noted that our finding that there is a cointegration relationship between tax revenue, public spending and GDP implies that tax revenue, public spending and GDP are closely bound. This indicates a one currency unit increase of the tax revenue leads to more than one currency unit increase in public spending. Unfortunately, on the GDP side, we did not find a significant relationship with public spending. Second, as tax revenue cause public spending, there is support for the "tax-and-spend" hypothesis. This implies that the ivorian government does not first engages in spending and then later, to pay for this spending, it collects tax revenue. Because such a situation will exacerbate fiscal imbalance bearing in mind all the difficulties of collecting tax revenue in Cote d'Ivoire. To resolve the problem of the persistent budget deficit in Côte d'Ivoire, a credible strategy should focus more on spending cuts rather than look for ways to raise revenues.

\section{References}

Abdulrasheed, B. (2017), "Causality between government expenditure and government revenue in Nigeria", Asian Journal of Economics and Empirical Research, 4(2), 91-98.

Ahiakpor, J. \& Amirkhaldi, S. (1989), "On the Difficulty of Eliminating Deficits with Higher Taxes: Some Canadian Evidence", Southern Economic Journal, Vol. 56, No. 2, pp. 24-31.

Alesina, A. \& Ardana, S. (1998), "Tales of Fiscal Contractions", Economic Policy, Vol. 13, No. 27, pp. 487-545.

Al-Zeaud, H. A. (2014), "The causal relationship between government revenue and expenditure in Jordan", Global Journal of Management and Business Research: B Economics and Commerce, Vol. 14, Issue 6, pp. 48-58.

Anderson, W., Wallace, M.S. \& Warner, J. T. (1986), "Government Spending and Taxation: What Causes What?” Southern Economic Journal, Vol. 52, No. 3, pp. 630-639.

Athanasenas, A., Katrakilikdis, C. \& Trachanas, E. (2014), "Government spending and revenues in the Greek economy: Evidence from nonlinear cointegration”, Empirica, 41(2), 365-376.

Aworinde, O. (2013), "The tax-spend nexus in Nigeria: Evidence from nonlinear causality", Economics Bulletin, 33(4), 3117-3130.

Aworinde, O. \& Ogundipe, M. (2015), "The tax-spend nexus in Nigeria: Evidence from asymmetric modelling”, The Journal of Developing Areas, 49(1), 39-51.

Baffes, J. \& Shah, A. (1994), "Causality and Comovement between Taxes and Expenditures: Historical Evidence from Argentina, Brazil, and Mexico", Journal of Development Economics, Vol. 44, No.2, pp. 311-331.

Baghestani, H. \& AbuAl-Foul, B. (2004), "The Causal Relation Between Government Revenue and Spending: Evidence from Egypt and Jordan", Journal of Economics and Finance, Vol. 28, No. 2, pp. 260-269.

Baghestani, H. \& McNown, R. (1994), "Do Revenues or Expenditures Respond to Budgetary Disequilibria?" Southern Economic Journal, Vol. 61, No. 2, pp. 311-322.

Barro, R. J. (1974), “Are Government Bonds Net Wealth”, Journal of Political Economy, Vol. 82, No.6, pp. $1095-1117$.

Barro, R. J. (1990), “Government Spending in a Simple Model of Endogenous Growth”, Journal of Political 
Economy, Vol. 98, No.5, S103-S124.

Bath, K. S., Nirmala, V. \& Kamaiah, B. (1993), "Causality between Tax Revenue and Expenditure of Indian States", The Indian Economic Journal, Vol. 40, No.4, pp. 109-117.

Blackley, P. R. (1986), "Causality between Revenues and Expenditures and the Size of the Federal Budget", Public Finance Quarterly, Vol. 14, No.2, pp. 139-156.

Blanchard, O. \& Perotti, R. (1999), "An Empirical Characterization of the Dynamic Effect of Changes in Government Spending and Taxes on Output", The Quarterly Journal of Economics, Vol. 117, No. 4, pp. $1329-1368$.

Bohn, H. (1991), "Budget balance through revenue or spending adjustment? Some historical evidence for the United States", Journal of Monetary Economics, 27(1991), 333-359.

Buchanan, J. M. \& Wagner, R. W. (1978), "Dialogues Concerning Fiscal Religion”, Journal of Monetary Economics, Vol. 4, No.3, pp. 627-636.

Carneiro, F.G., Faria, J. R. \& Barry B. S. (2004), "Government Revenues and Expenditures in Guinea-Bissau: Causality and Cointegration", Africa Region Working Paper Series No. 65

Chang, T. \& Ho, Y. H. (2002a), "Tax or Spend, What Causes What: Taiwan's Experience", International Journal of Business and Economics, Vol.1, No. 2, pp. 157-165.

Chang, T. \& Ho, Y. H. (2002b), “A Note on Testing Tax-and-Spend, Spend-and-Tax or Fiscal Synchronization: The Case of China", Journal of Economic Development, Vol. 27, No.1, pp. 151-160.

Chang, T., \& Chia, G. (2009), "Revisiting the government revenue - expenditure nexus: Evidence from 15 OECD countries based on the panel data analysis", Finance a úve-Czech Journal of Economics and Finance, 59 (2).

Chang, T., Liu W. R. \& Caudill, S. B. (2002), "Tax-and-spend, spend-and-tax, or fiscal synchronization: New evidence for ten countries", Applied Economics, Vol. 34, No.12, pp. 1553-61.

Cheng, S. B. (1999), "Causality Between Taxes and Expenditures: Evidence from Latin American Countries", Journal of Economics and Finance, Vol.23, No.2, pp. 184-192.

Darrat, A. F. (1998), Tax and Spend, or Spend and Tax? An Inquiry into the Turkish Budgetary Process", Southern Economic Journal, Vol. 64. No.4. pp. 940-956.

Darrat, A. F. (2002), "Budget Balance through Spending cuts or Tax Adjustments?" Contemporary Economic Policy, Vol. 20, No.3, pp. 221-233.

De Castro, F., Gonzalez-Paramo, J. M. \& Hernandez de Cos P. (2004), "Fiscal Consolidation in Spain: Dynamic Interdependence of Public Spending and Revenues", Investigaciones Economicas, Vol. XXVIII, No.1, pp. 193-207.

Dhanasekaran, K. (2001), "Government Tax Revenue, Expenditure and Causality: The Experience of India", India Economic Review, Vol. 2, No. 2, pp. 359-379.

Dickey, D.A. \& Fuller, W. A. (1979), "Distribution of the Estimators for Autoregressive Time Series with a Unit Root", Journal of American Statistical Association, vol. 74, pp. 427-431.

Dogan E. (2013), “Does 'revenue-led spending' or 'spending-led revenue' hypothesis exist in Turkey?”, British Journal of Economics, Finance and Management Sciences, 8(2), 62-75.

Elliott, G., Rothenberg, T. J. \& Stock, J. H. (1996), "Efficient Tests for an Autoregressive Unit Root", Econometrica, 64(4), 813-836.

Ewing, B. \& Payne, J. (1998), "Government Revenue-Expenditure Nexus: Evidence from Latin America", Journal of Economic Development, Vol. 23, No.2, pp. 57-69.

Fasano, U. \& Wang, Q. (2002), "Testing the Relationship Between Government Spending and Revenue: Evidence from GCC Countries", International Monetary Fund Working Paper 201, November, 2002.

Friedman, M. (1978), “The Limitations of tax Limitation”, Policy Review, Vol. 5, No.78, pp.7-14.

Fuess, M. S., Hou, W. J. \& Millea, M. (2003), “Tax or Spend, What Causes What? Reconsidering Taiwan's Experience", International Journal of Business and Economics, Vol. 2, No.2, pp. 109-119.

Giavazzi, F. \& Pagano, M. (1990), "Can Severe Fiscal Contractions be Expansionary? Tales of Two Small European Countries", NBER Macroeconomics Annual, Vol. 5, pp. 75-111.

Giavazzi, F., Jappelli, T. \& Pagano, M. (2000), "Searching for Non-Linear Effects of Fiscal Policy: Evidence from Industrial and Developing Countries", European Economic Review, Vol. 44, No. 7, pp. 1259-1290.

Granger, C. W. J. (1969), "Investigating causal relations by econometric models and cross-spectral methods", Econometrica, vol. 37, pp. 424-438.

Guajardo, J. A. T. \& Pagan J. A. (2003), “Government Spending Taxation and Oil Revenue in Mexico", Review of Development Economics, Vol. 7, No.1, pp. 152-164.

Hasan, M. \& Lincoln, I. (1997), "Tax Then Spend or Spend Then Tax? Experience in the UK", Applied Economic Letters, Vol. 4, No.4, pp. 237-239.

Hondroyiannis, G. \& Papapetrou, E. (1996), “An Examination of the Causal Relationship between Government Spending and Revenue: A Cointegration Analysis", Public Choice, Vol. 89, No.3-4, pp. 363-374. 
Hoover, K. D. \&. Sheffrin S. M (1992), “Causation, Spending, and Taxes: Sand in the Sandbox or Tax Collector for the Welfare State”, American Economic Review, Vol. 82, No.1, pp. 225-248.

Ibrahim, T. (2017), "Government expenditure-revenue nexus reconsidered for Nigeria: Does structural break matter?", University Library of Munich, Germany, MPRA Paper No. 86220.

Inder, B. (1993), "Estimating long-run relationships in economics: A comparison of different approaches", Journal of Econometrics, Vol. 57, No.1-3, pp. 53-68.

Islam, M. Q. (2001), "Structural break, unit root, and the causality between government expenditures and revenues", Applied Economics Letters, 8, 565-567.

Jones, J. D. \& Joulfaian, D. (1991), "Federal Government Expenditures and Revenues in the Early Years of the American Republic: Evidence from 1792-1860”, Journal of Macroeconomics, Vol. 13, No.1, pp. 133-155.

Joulfaian, D. \& Mookerjee, R. (1991), "Dynamics of Government Revenues and Expenditures in Industrial Economies", Applied Economics, Vol. 23, No.12, pp. 1839-1844.

Keho, Y. (2010), "Budget balance through revenue or spending adjustments? An econometric analysis of the Ivorian budgetary process: 1960-2005", Journal of Economics and International Finance, 2:1-11.

Koren, S. \& Stiassny, A. (1998), “Tax and Spend or Spend and Tax? An International Study”, Journal of Policy Modeling, Vol. 20, No.2 pp. 163-191.

Li, X. (2001), "Government Revenue, Government Expenditure, and Temporal Causality: Evidence from China", Applied Economics, Vol. 33, No.4, pp. 485-497.

Lucas, R. E. (1988), "On the Mechanics of Economic Development”, Journal of Monetary Economics, Vol. 22, No. 1, pp. 3-42.

Lukovic, S. \& Grbic, M. (2014), "The causal relationship between government revenue and expenditure in Serbia", Economic Themes, 52(2), 127-138.

Manage, N. \& Marlow, M. L. (1986), "The Causal Relation Between Federal Expenditures and Receipts", Southern Economic Journal, Vol. 52, No. 3, pp. 617-629.

Marlow, M. L. \& Manage, N. (1987), "Expenditures and Receipts: Testing for Causality in State and Local Government Finances", Public Choice, Vol. 53, No. 3, pp. 243-255.

Meltzer, A. H. \& Richard, S. F. (1981), "A Rational Theory of Size of the Government”, Journal of Political Economy, Vol. 89, No. 5, pp. 914-927.

Miller, S. M. \& Russek, F. S. (1990), "Co-integration and Error-Correction Models: Temporal Causality Between Government Taxes and Spending”, Southern Economic Journal, Vol. 57, No. 1, pp. 221-229.

Mithani, D.M. \& Khoon, G. S. (1999), "Causality between Government Expenditure and Revenue in Malaysia: A Seasonal Cointegration Test”, ASEAN Economic Bulletin 16, pp. 68-79.

Mohanty, A. R. \& Mishra, B. R. (2017), "Cointegration between government expenditure and revenue: Evidence from India", Advances in Economics and Business 5(1): 33-40.

Musgrave, R. (1966), "Principles of Budget Determination”, In Public Finance: Selected Readings, H. Cameron et W. Henderson (eds.). New York: Random House.

Narayan, P. K. (2005), “The Government Revenue and Government Expenditure Nexus: Empirical Evidence from Nine Asian Countries", Journal of Asian Economics, Vol. 15, pp. 1203-1216.

Nwosu, D. C. \& Okafor, H. O. (2014), "Government revenue and expenditure in Nigeria: A disaggregated analysis", Asian Economic and Financial Review, 4(7): 877-892.

Obeng, S. K. (2015), "A causality test of the revenue-expenditure nexus in Ghana”, ADRRI Journal of Arts and Social Sciences, Ghana: Vol. 11, No. 11(1), pp. 1-19, ISSN: 2343-6891.

Owoye, O. (1995), "The Causal Relationship Between Taxes and Expenditures in the G7 Countries: Cointegration and Error Correcting Models", Applied Economic Letters, Vol. 2, No.1, pp. 19-22.

Paleologou, S. (2013), "Asymmetries in the revenue-expenditure nexus: A tale of three countries", Economic Modelling, 30, 52-60.

Park, W. K. (1998), "Granger Causality between Government Revenues and Expenditures in Korea”, Journal of Economic Development, Vol. 23, No.1, pp. 145-155.

Payne, J. E., Ewing, B. T. \& Cebula, R. J. (2003), "Revenue-Expenditure Nexus in a Transition Economy: Evidence from Croatia", Economic Trends and Economic Policy, Vol. 12, No. 93, pp. 27-37.

Peacock, A. \& Wiseman, J. (1979), "Approaches to the Analysis of Government Expenditures Growth", Public Finance Review, Vol. 7, No.1, pp. 3-23.

Perron, P. (1989), “The Great Crash, the Oil Price Shock, and the Unit Root Hypothesis”, Econometrica, Vol. 57, No.6, pp. 1361-1401.

Pesaran, H., Shin, Y. \& Smith, R. J. (2001), "Bounds Testing Approaches to the Analysis of Level Relationships", Journal of Applied Econometrics, Vol. 16, No.3, pp. 289-326.

Phillips, P. (1995), "Fully Modified Least Squares and Vector Autoregression”, Econometrica, 63, 1023-1078.

Phillips, P. C. B. \& Hansen B. E. (1990), "Statistical inference in instrumental variables regressions with I(1) processes", Review of Economie Studies, 51, 99-125. 
Phillips, P. C., \& Perron, P. (1988), “Testing for Unit Root in Time Series Regression”, Biometrica, 75, 335-346.

Phiri, A. (2016), "Asymmetries in the revenue-expenditure nexus: new evidence from South Africa", Empirical Economics, 1-33.

Ram, R. (1988a), "Additional Evidence on Causality Between Government Revenue and Government Expenditure”, Southern Economic Journal, Vol. 54, No. 3, pp. 763-769.

Ram, R. (1988b), "A Multicountry Perspective on Causality Between Government Revenue and Government Expenditure”, Public Finance, Vol. 43, No.2, pp. 261-270.

Romer, P.M. (1990), “Endogenous Technological Change”, Journal of Political Economy, Vol. 98, No.5, pp. 71102.

Stock, J. \& Watson, M. W. (1993), “A Simple Estimator of Cointegrating Vectors in Higher Order Integrated Systems", Econometrica, Vol. 61, No.4, pp. 783-820.

Takumah, W. (2014), "The dynamic causal relationship between government revenue and government expenditure nexus in Ghana", University Library of Munich, Germany.

Tiwari, A. \& Mutascu, M. (2016), "The revenues-spending nexus in Romania: A TAR and MTAR approach", Economic Research-Ekonomska Istrazivanja, 29(1), 735-745.

Toda, H. Y. \& Yamamoto, T. (1995), "Statistical Inference in Vector Autoregressions with possibly Integrated Processes", Journal of Econometrics, Vol. 66, N¹-2, pp. 225-250.

Vamvoukas, G. (1997), "Budget expenditures and Revenues: An Application of the Error Correction Modeling", Public Finance, Vol. 52, No. 1, pp. 139-143.

von Furstenbeg, Green, G. M., J. \& Jeong H. (1986), "Tax and Spend or Spend and Tax", The Review of Economics and Statistics, Vol. 68, No. 2, pp. 179-188.

Yinusa, D. O. \& Adedokun, A. (2017), "Fiscal synchronisation or institutional separation: An examination of tax-spend hypothesis in Nigeria", Journal of Finance, 5(3), 80-87.

Zivot, E. \& Andrews, D. W. K. (1992), "Further Evidence on the Great Crash, the Oil-Price Shock, and the Unit Root Hypothesis", Journal of Business and Economic Statistics, Vol. 10, No. 3, pp. 251-270. 